\title{
Determinants of bank net interest margins in Fiji, \\ a Small Island Developing State
}

\begin{abstract}
This paper investigates the determinants of net interest margins (NIM) of banks in Fiji, a small island developing state in the South Pacific, over the 2000-2010 period. Based mainly on the Ho and Saunders (1981) dealership model and extensions thereto, this study uses a number of panel data estimation techniques to control for possible heterogeneity across banks and various assumptions about errors. Consistent with the theoretical model, NIM has a positive association with implicit interest payment, operating cost, market power and credit risk, and a negative association with the quality of management and liquidity risk. However, the association with bank capital and opportunity cost of required reserves do not conform to expectations. Policy implications are discussed.
\end{abstract}

Keywords: Fiji, South Pacific, bank, net interest margin

JEL Classifications: C23, G21

\section{Introduction}

Banks deposit mobilisation and credit allocation functions have important implications for economic growth and development (Levine, 1997, 2005). The significance of this intermediation process is likely to be greater in economies with thin financial markets and small non-bank sectors; here, a larger percentage of firms and individuals are likely to depend on banks for external funding. However, the level of intermediation and thus 
economic activity may be impeded by, among others, banks' net interest margins (Khediri and Khedhiri, 2011), making it important to examine not only relative margins but also to understand their determinants, so that appropriate policy may be developed and actioned. Moreover, regularly updating our knowledge of bank interest margins helps better monitor banking efficiency over time and better evaluate their price signal implications (Hawtrey, and Liang, 2008).

Literature on determinants of bank net interest margins (NIM) abound. However, the determinants and/or their influence vary across countries as well as regions of the world (e.g. Doliente, 2005; Hawtrey and Liang, 2008; Maudos and Solis, 2009). For example, while bank capital and credit risk are found to be significantly and positively related to NIM in developed countries (e.g. Saunders and Schumacher, 2000), the relationship has been found to be significant but negative in some Latin American countries (Brock and Suarez, 2000). In the small island developing states (SIDS) of the South Pacific little is known about the determinants of bank net interest margins. Accordingly, this study, using Fiji as an example, attempts to fill this void in literature. Several other country and banking sector characteristics make this study interesting and important, including (i) persistently sluggish economic growth ${ }^{1}$; (ii) a profoundly bank-dominated financial sector, in turn controlled by foreign banks; and (iii) continual structural and regulatory change to the banking sector.

While Fiji's financial sector may be the largest and most advanced in the South Pacific (ADB, 2005), bond markets are infinitesimal and confined to government and statutory bodies and the stock market remains small, illiquid and inefficient after more than 30

\footnotetext{
${ }^{1}$ Asian Development Outlook for Fiji 2011, http://www.adb.org/documents/books/ado/2011/ado2011 fij.pdf [Accessed: August, 2011].
} 
years of existence (Sharma and Roca, 2012). Over the 1970-2007 period, the banking sector provided $92 \%$ of all financial institution credit to the private sector. Also in this period, the average banking to stock market activity was in excess of 300 times (Sharma and Brimble, 2011). Moreover, banking activities are still highly traditional, confined mainly to deposit-lending activities; investment banking and venture capital are virtually non-existent (Sharma and Gounder, 2011). However, bank clients may access modes of delivery and services prevalent in industrialised countries, including telephone and internet banking.

Although a SIDS, with a population of less than a million, Fiji's banking sector has undergone a number of important structural and regulatory changes. For example, a number of foreign and international banks, including Bank of New Zealand (19871990), Citibank (1970-1978), Barclays Bank International (1972-1985), HSBC (19801988), Habib Bank Limited (1991-2005), and Bank of Hawaii (1993-2001) have entered and exited the system, with either ANZ (Australia New Zealand Bank Limited) or WBC (Westpac Banking Corporation Limited), the two pioneers and largest banks, acquiring their businesses ${ }^{2}$. The only local bank, the state-owned National Bank of Fiji (1974-1988), has also had to exit the system with its business acquired by Commonwealth Bank of Australia (Sharma, 2009). Similarly, highlights of regulatory reforms include removal in 1980s and 1990s of a number of government regulations such as the maximum loans to deposit ratios, mandatory lending to selected sectors, compulsory investment in government securities, and regulations on deposit and lending rates. Recent new and more important regulations include maintaining a maximum interest spread of four per cent and providing products and services suitable and

\footnotetext{
${ }^{2}$ Currently there are five commercial banks operating in Fiji; ANZ (Australia and New Zealand Bank Limited), WBC (Westpac Banking Corporation), Bank of Baroda (BOB), Bank South Pacific and Colonial National Bank (CNB).
} 
affordable to the needs of poor and low-income earners and individuals and micro and small enterprises.

Thus, our study estimates for the first time, the determinants of bank interest margins in a foreign bank dominated, bank-controlled, economic-growth challenged, small island developing state in the South Pacific. It does so by incorporating methodologies of both the seminal study by Ho and Saunders (1981) and subsequent studies, which include both the average operating costs and non-traditional activities as determinants of interest margin.

The results obtained indicate that the main determinants of net interest margins of banks in Fiji, and possibly elsewhere in the South Pacific ${ }^{3}$, are implicit interest payments, market power, quality of management and operating costs; all have the expected signs and are significant. Results also show that some determinants may not be as influential as in other countries and/or regions. For example, credit and liquidity risks while exhibiting the expected relationships are not significant. Moreover, bank capital and opportunity cost of required reserves, are, contrary to results of a number of other studies, negative and insignificant, due perhaps to relatively cheap bank funding costs in Fiji and regulatory requirements being a decent alternative for use of funds in the absence of new bankable projects; our results though are similar to some Asian experiences. From a policy perspective, there is a need to implement measures aimed at increasing competition and efficiency in Fiji's banking system; fortunately, contrary to expectations, regulatory requirements such as minimum capital appear to have little implications for cost of intermediation and margin settings.

\footnotetext{
${ }^{3}$ The major banks in Fiji-ANZ and WBC - are major banks across the South Pacific.
} 
The rest of the paper is organised as follows. Section II reviews existing literature. Section III describes the empirical model and data. Section IV reports the empirical results and section $\mathrm{V}$ concludes.

\section{A brief review of literature}

The Ho and Saunders (1981) seminal risk-averse 'dealership' model, an extension of the hedging hypothesis and the expected utility approach, has become the standard for examining and understanding the determinants of bank interest margins. The model assumes that the degree of risk aversion, the market structure, the average size of bank transactions and the variance on the interest rate on loans and deposits importantly influence bank interest margins. Using data on 100 major US banks, over the 19761979 quarterly period, the authors' firstly estimate a regression of individual bank's interest margin against some bank-specific variables, including implicit interest payment(IPP), opportunity cost of required reserves (OCRR), and default premium; the constant term represents a 'pure spread', not explained by bank-specific characteristics. A regression of this 'pure spread' is subsequently estimated as a function of the volatility of interest rates.

Many researchers have subsequently attempted to extend, refine and generally modify the Ho and Saunders (1981) model to capture other bank- and country-specific variables. Researchers have also attempted to employ different analytical tools and/or condense the analysis into one stage from the original two-step approach. Studies have also spaned different countries and regions of the world, both single-and cross-country. For example, Angbazo (1997), while also using the US bank data but for a different 
period (1989-1993), introduces credit risk (CR), interest rate risk (IRR) and the interaction between these risks into the model ${ }^{4}$. Results show that NIM are negatively related to the degree of global competition and cost structures and positively to gross income volatility and marker power. Subsequently, Saunders and Schumacher (2000) estimate the model using US and six European country bank data for the 1988-1995 period and Brock and Suarez (2000) estimate it for five Latin American banks. Interestingly, while Saunders and Schumacher (2000) find BC and CR to be significantly and positively related to NIM, Brock and Suarez (2000) find the relationships to be significant but negative; other relationships are similar.

More recently, Maudos and Guevara (2004) include operating costs as a determinant of net interest income and estimate the model for the main European banking sectors (Germany, France, UK, Italy and Spain) over the 1993-2000 period. They also substitute the structural measure of market power (market concentration indicators) with a more direct measure (Lerner index, LI). Results show that LI (Lerner Index), OC (opportunity cost), RA (degree of risk aversion) IRR (internal rate of return), CR (credit risk), IIP (implicit interest payment), OCRR (opportunity cost of required reserves) and QM (quality of management) are all positively related to NIM; on the other hand, QM and size of transactions are negatively correlated with NIM. Martinez and Mody (2004) examine the impact of foreign participation and concentration on Latin American bank (Argentina, Chile, Colombia, Mexico and Peru) spreads and find both the spread and the cost of operation of foreign banks to be lower than that of domestic banks. Moreover, the spreads of foreign banks which acquired domestic institutions were

\footnotetext{
${ }^{4}$ Some of the more common variables (with their acronyms) used in NIM studies include: credit risk (CR), implicit interest payments (IIP), interest rate risk (IRR), Lerner Index (LI, a direct measure of market power), operating costs (OC), opportunity cost of required reserves (OCRR), quality of management $(\mathrm{QM})$ and bank capital (BC, also a proxy for risk aversion, $\mathrm{RA})$.
} 
higher than those that started anew. Results also show spreads are influenced positively and significantly by the degree of concentration.

Using the representative bank approach and building on the work of Maudos and Guevara (2004), Hawtrey and Liang (2008) examine the determinants of NIM in 14 OECD countries over the 1987-2001 period. Results show that national industry margins are influenced by market power, OC (opportunity cost), IIP (implicit interest payment) and QM (quality of management). Gelos (2006) examines the NIM of Latin American (14 countries) and other emerging economies (71 countries). Results show a positive relationship with deposit rate, OCRR (opportunity cost of required reserves), legal structure and taxes and a negative one with GDP and foreign ownership.

Maudos and Solis (2009) develop an integrated model by consolidating the methodologies of the original (Ho and Saunders, 1981) and a number of subsequent studies (including, Angbazo, 1997 and Maudos and Fernandez de Guevara, 2004) and estimate it for the Mexican banking system. They find that OC, LI and IRR have the most significant and positive impacts on margins. In addition, a positive relationship is observed between QM, IIP and NIM. Khediri and Khedhiri (2011) employ randomand fixed-effect techniques and panel data to examine the determinants of bank NIM in Tunisia. Results show that OC (opportunity cost), OCRR (opportunity cost of required reserves), IIP (implicit interest payment) and BC (bank capital) significantly and positively influence NIM, and QM (quality of management), significantly but negatively. 


\section{Data and empirical model}

The period of our study is 2000-2010 since this is the most complete relevant data available for four of the five banks in Fiji. The four banks include: ANZ, WBC, BOB and $\mathrm{CNB}$ - all foreign branches and not listed on the local stock exchange. The fifth bank-Bank of South Pacific, also foreign-commenced operations in 2006 by acquiring the business of another foreign bank-Habib Bank Limited (a Pakistani bank). The data is obtained from Reserve Bank of Fiji's online database on banks' "published disclosure statements"5. The assets, loans and deposits of the four banks average around $98 \%$ of the total of all banks in Fiji.

The dependent variable is NIM (net interest margin), defined as the difference of total interest income and interest expense to total assets. The independent variables include the following: implicit interest payment (IIP), operating cost (OC), opportunity cost of required reserves (OCRR), credit risk (CR), bank capital (BC), quality of management (QM), liquidity risk (LR), and Lerner index (LI). The independent variables are described below.

Implicit interest payment (IIP) is defined as the ratio of operating expenses net of noninterest income to total assets. In competing for deposits, in lieu of paying an explicit interest on deposits, banks are more likely to reward depositors via implicit payments such as free services; a positive sign is expected. Operating cost (OC) is defined as the ratio of operating expenses to total assets. Banks experiencing high operating costs are expected to apply high margins; a positive relationship is expected. Opportunity cost of required reserves (OCRR) is defined as the ratio of cash plus

\footnotetext{
${ }^{5} \mathrm{http}: / /$ www.reservebank.gov.fj/default.aspx?page=publishedDS
} 
balances with Reserve Bank of Fiji (RBF) to total assets. Both cash in vault (to meet withdrawal demands of depositors) and statutory required deposit balances with RBF (central bank) are mandatory and maintained at no interest and low interest, respectively. Banks with greater volumes of such balances are expected to have greater NIM; a positive sign is expected.

Credit risk (CR) is defined as general reserves for credit losses to gross loans. Due to lack of data, many studies use proxies such as (net) loans to total assets to examine the influence of this variable on NIM. The lending function of banks expose them to CR; banks are therefore expected to apply an implicit risk premium in the interest rates charge - a positive relationship is expected. Bank capital (BC) is defined as the ratio of capital to total assets. Banks in Fiji are subject to a minimum $8 \%$ capital adequacy requirement; equity financing being more expensive compared to debt financing, it is expected that this regulatory requirement would translate into a higher margin to cover for the higher costs; a positive sign is expected. This ratio may also be used as a proxy for banks' degree of risk aversion (RA).

Quality of management (QM) is defined as the ratio of operating expenses to gross income, i.e. the operating costs necessary to generate one unit of gross income; the higher the quality of bank management, the higher the interest margins, on the grounds that a high quality management implies ability to raise low cost liabilities and invest in highly profitable assets (Angbazo, 1997; Maudos and Guevara, 2004). Thus, a rising ratio indicates a falling QM and therefore a lower NIM; a negative sign is expected. Liquidity risk (LR) is defined as the ratio of total liquid assets to total assets; the expected sign is negative. Finally, the Lerner index (LI) is used as a direct measure of 
the level of competition in the system, i.e. market power of banks. Following Hawtrey and Liang (2008), we define LI as the ratio of the difference between price and average cost divided by price, equivalent to the difference between total revenue and total cost divided by total revenue. The values of the index range from 0 (perfect competition) to 1 (monopoly); the expected sign is positive. We have not included interest rate volatility since interest rates in Fiji are not influenced by the market, i.e. there is no rate setting by the Reserve Bank as one might find in say, Australia, and funding sources are predominantly domestic.

Accordingly, the regression estimates are based on the following equation:

$\mathrm{NIM}_{i t}=\beta_{1 i t}+\beta_{2} \mathrm{IIP}_{i t}+\beta_{3} \mathrm{OC}_{i t}+\beta_{4} \mathrm{OCCR}_{i t}+\beta_{5} \mathrm{BC}_{i t}+\beta_{6} \mathrm{CR}_{i t}+\beta_{7} \mathrm{QM}_{i t}+\beta_{8} \mathrm{LR}_{i t}+\beta_{9} \mathrm{LI}_{i t}+$ $\mu_{\text {it }}$

where, $\mathrm{NIM}_{i t}$ is the NIM of bank $i(i=1, \ldots, 4)$ at year $t(t=1 \ldots, 11) ; \mathrm{OC}_{i t}$ the operating costs; IIP $_{i t}$ the implicit interest payments; $\mathrm{OCCR}_{i t}$ the opportunity cost of required reserves; $\mathrm{BC}_{i t}$ the bank capital; $\mathrm{CR}_{i t}$ the credit risk; $\mathrm{QM}_{i t}$ the quality of management; $\mathrm{LR}_{i t}$ the liquidity risk; $\mathrm{LI}_{i t}$ the Lerner index; $\beta_{1 i t}$ is a constant, and $\mu_{i t}$ the error term. This general linear regression model cannot be estimated in this form as there are a larger number of unknown parameters than data points. However, using different assumptions about the parameters and errors allows us to estimate three different forms of the above general regression model; pooled regression or panel least squares (PLS), fixed effects model (FEM) and the random effects model (REM). The PLS model assumes that there are no time or cross-sectional effects whereas FEM assumes all individual bank differences are captured by differences in the intercept parameters and 
REM, while assuming individual firm differences are captured by the intercept parameters, treat individual firm differences as random rather than fixed. Serial correlation in PLS is checked through the possibility that the error is a first order autoregressive $(\mathrm{AR}(1))$ process. The significance of the coefficient of $\mathrm{AR}(1)$ term indicates serial correlation in the errors and the evidence that the error in each time period contains a time constant omitted factor. With serial correlation, the PLS is likely to be biased and inconsistent. This bias, arising from omitting a time constant variable, is sometimes also referred to as unobserved heterogeneity bias. The unobserved individual heterogeneity, however, can be appropriately modelled through FEM and REM. Fixed effects estimation allows for arbitrary correlation between the unobserved effect and the observed explanatory variables whereas the REM regards the unobserved effects are uncorrelated with the explanatory variables. Indeed the key issue in modeling the assumptions about the unobserved effects and explanatory variables is whether or not the former is uncorrelated with the latter (Wooldridge, 2002). Consequently we estimate all three models, use appropriate econometric tests to identify the appropriate model and discuss the results with policy implications.

\section{Empirical results and analysis}

Table 1 summarises the regression results using different methodologies: Panel Least Squares (PLS), Fixed Effects Model (FEM), Random Effects Model (REM), PLS with AR(1) errors and REM with period clustered standard errors (PCSE).

Table 1 here 
Except for OCCR (opportunity cost of required reserves) and BC (bank capital—in only one case), the signs are remarkably consistent across the different methodologies. Moreover, the association of NIM with IIP (implicit interest payment), LI (Lerner Index), QM (quality of management) and OC (opportunity cost) are consistently and highly significant across all regressions. The coefficient of $A R(1)$ is significant in the PLS estimates which indicate the presence of an observed effect. This indicates that either FEM or REM is preferable to PLS. To compare the FEM and REM, we conducted the redundant fixed effects-likelihood ratio test; results of which are presented in panel A of table 2. As the results of panel A shows, the $p$ value of the Chisquare test suggests that the null cannot be rejected and that the cross section effects are redundant. However, we can reject the null that fixed effects are redundant.

The results thus suggest that the REM is the appropriate model. Nonetheless, since REM assumes that the random error terms are uncorrelated with the explanatory variables, a correlated random effects test of REM is required. We do this using the Hausman (1978) test to compare the fixed and random effects estimates of the coefficients; results are presented in panel B of table 2. As the panel show, the null hypothesis of no misspecification cannot be rejected at the 5\% level. We therefore conclude that REM assumptions hold. With the assumption of the REM, the key consequence is that the residuals for a given firm are correlated across periods (Angrist and Pischke, 2008). As a result, we estimate REM with robust period cluster estimation (PCSE). Output from REM (PCSE) show the signs of all the coefficients are very consistent with the results from PLS and REM. Robustness is also confirmed through the consistent estimates of the standard errors. The REM with PCSE regression results are utilised to discuss the determinants of NIM. 


\section{Table 2 here}

As expected, there is a positive and significant relationship between IIP (implicit interest payment) and NIM, indicating that banks in Fiji may attempt to recover implicit interest payments via margin setting (see table 3 for predicted and actual signs). Our results are consistent with other studies, including Saunders and Schumacher (2000), Maudos and Solis (2009), Hawtrey and Liang (2008) and Khediri and Khedhiri (2011). A positive and significant relationship is also shown between OC and NIM, indicating that banks in Fiji are likely to transfer some of their operating costs to their clients. This result is consistent with Brock and Suarez (2000), Maudos and Guevara (2004), Gelos (2006) and Hawtrey and Liang (2008).

\section{Table 3 here}

Surprisingly, the relationship between BC (bank capital) and NIM is not positive as expected but not significant either; a number of studies report a positive and significant relationship (e.g. Angbazo, 1997; Saunders and Schumacher, 2000; Maudos and Solis, 2009 and Khediri and Khedhiri, 2011), which may imply a trade-off between realising a degree of stability in the banking sector on one hand and achieving an efficient level of cost of intermediation on the other (Doliente, 2005). In the case of Fiji, however, only not do banks appear not to be passing on the cost of the more expensive equity financing (compared to debt financing) to their clients, they also appear willing to maintain high levels of capital; indeed, they have substantially increased their capital base in recent years, in some cases, up to twice the minimum $8 \%$ legal requirement. Perhaps, the cost of equity financing is not too expensive in Fiji; perhaps, debt financing 
too is relatively cheap, so that the cost of funding is not an issue for banks. Thus, pursuing regulatory objectives of bank stability in Fiji may not have negative implications for cost of financial intermediation. Our results are similar to Thailand's across the four South East Asian countries (Indonesia, Malaysia, Philippines and Thailand) in Doliente's (2005) study.

The relationship between OCRR (opportunity cost of required reserves) and NIM is also not positive as expected but again not significant either; a number of studies report a positive and significant relationship (Saunders and Shumacher, 2000; Maudos and Solis, 2009; Maudos and Guevara, 2004; and Khediri and Khedhiri, 2011). Taken together with the $\mathrm{BC}$ result above, perhaps, banks in Fiji do not mind the regulatory requirements. Perhaps, there really is a lack of bankable projects in Fiji (ADB, 2005) and regulatory requirements provide decent alternative use of funds.

The credit risk variable displays the expected positive but not a very significant relationship (only at $10 \%$ ); most studies report a significant relationship, either positive (Saunders and Schumacher, 2000; Maudos and Solis, 2009; Hawtrey and Liang, 2008) or negative (Doliente, 2005; Brock and Suarez, 2000). A significant negative relationship indicates that NIM falls as the quality of loans declines (due perhaps to inadequate provisioning for loan losses or regulators reluctance to close banks in trouble, may even encourage high risk taking behaviour-banks with large bad loans may lower spreads in trying to solve problems, Brock and Suarez, (2000)); a significant positive association indicates the converse; in the case of Fiji, NIM may not be as significantly influenced by the level of banks' exposure to credit risk or expectations of default as by IIP, OC, QM and LI. 
As expected, the relationship between QM (quality of management) and NIM is negative and significant, consistent with Angbazo (1997); Maudos and Guevara (2004), Hawtrey and Liang (2008) and Khediri and Khedhiri (2011). The LR displays the expected negative relationship with NIM but is not significant, consistent with Doliente (2005) but only for two of the four countries in the sample. Finally, consistent with other studies (Maudos and Solis, 2009; Maudos and Guevara, 2004; Hawtrey and Liang, 2008), market power in Fiji too appears to significantly and positively influence bank NIM, reflecting the fact that banks with greater market power may charge a higher loan rate and offer a lower deposit rate; we have used LI (Lerner Index) as a direct measure of market power.

\section{Conclusion}

Based on the seminal Ho and Saunders (1981) and extensions thereto, and using alternative panel data estimation techniques, this study examines the determinants of bank net interest margin (NIM) in Fiji, a representative small island developing state in the South Pacific. As expected and consistent with existing literature, NIM is positively associated with implicit interest payments (IIP), operating cost (OC), credit risk (CR), and market power (measured by the Lerner Index) and negatively with the quality of management (QM) and liquidity risk (LR). Of these, CR and LR are not significant. More interestingly, contrary to a number of other studies, based on developed, developing and emerging economy bank data, bank capital (BC) and opportunity cost of required reserves (OCRR) exhibit an unexpected negative but insignificant association; most studies find a positive and significant association. 
From a policy perspective, there is a need to implement measures aimed at increasing competition and efficiency in Fiji's banking system; thus, examining, among others, the efficiency and profitability (and its determinants) of banks in Fiji may be useful areas of further research. Fortunately, contrary to expectations, regulatory requirements such as minimum capital appear to have little implications for margin setting; thus, pursuing regulatory objectives of bank stability in Fiji may not have negative implications for cost of financial intermediation. Further research on determinants of NIM in Fiji may use the two-step regression approach advanced by Ho and Saunders (1981) to investigate the influence of bank-specific characteristics as well as macroeconomic factors such as inflation and economic growth rates. Moreover, a larger time series data, when available, may be useful. 


\section{References}

ADB (2005) Private Sector Assessment for Fiji Islands: 'Promise Unfulfilled', the Asian Development Bank, Manila.

Angbazo, L. (1997) Commercial bank net interest margins, default risk, interest rate risk and off-balance sheet banking, Journal of Banking and Finance, 21, 55-87.

Angrist, D. J. and J. Pischke (2008) Mostly Harmless Econometrics: An Empiricist's Companion, Princeton University Press, New Jersey.

Brock, P. and L. R. Suarez (2000) Understanding the behaviour of bank spreads in Latin America, Journal of Development Economics, 63, 113-134.

Doliente, J. S. (2005) Determinants of bank net interest margins in Southeast Asia, Applied Financial Economic Letters, 1, 53-7.

Gelos, R. (2006) Banking spreads in Latin America, IMF working paper, WP/06/44, IMF.

Hausman, J. A. (1978) Specification Tests in Econometrics, Econometrica, 46, 12511272.

Hawtrey, K. And H. Linag (2008) Bank interest margins in OECD countries, North American Journal of Economics and Finance, 19, 249-260.

Ho, T. and A. Saunders (1981) The determinants of bank interest margins: theory and practice, Journal of Financial and Quantitative Analysis, 16, 581-600

Khediri, K. B. And H. Ben-Khedhiri (2011) Determinants of bank net interest margin in Tunisia: a panel data model, Applied Economics Letters, 18, 1267-1271.

Levine, R. (1997) Financial development and economic growth: views and agenda, Journal of Economic Literature, 35, 688-726.

Levine, R. (2005) Finance and Growth: Theory and Evidence, In: Handbook of Economic Growth, Eds: Aghion, P. and S. Durlauf, Elsevier: 865-934. 
Maudos, J. and J. F. de Guevara (2004) Factors explaining the interest margin in banking sectors of the European Union, Journal of Banking and Finance, 28, 22592281.

Maudos, J., and L. Solis (2009) The determinants of net interest income in the Mexican banking system: an integrated model, Journal of Banking and Finance, 33, 192031.

Martinez, M. S. and A. Mody (2004). How foreign participation and market concentration impact bank spreads: evidence from Latin America, Journal of Money, Credit and Banking, 36, 511-537.

Saunders, A. and L. Schumacher (2000) The determinants of bank interest rate margins: an international study, Journal of International Money and Finance, 19, 813-832.

Sharma, P., 2009. Financial Development in Fiji, Griffith University, Australia (Unpublished PhD thesis).

Sharma, P. and E. Roca (2012) It is Time to Re-examine the role of stock markets in developing economies, Journal of Asia-Pacific Business, 13, forthcoming.

Sharma, P. and M Brimble (2011) Sustainable Development in the Small States of the South Pacific: Toward a Corporate Social Responsibility for International Banks, Fijian Studies, forthcoming.

Sharma, P. and Gounder, N. Supply side obstacles to financing the private sector: empirical evidence from a small island developing state, Discussion Papers in Finance, 1-2011, Griffith University.

Wooldridge, J. (2002) Econometric Analysis of Cross Section and panel Data, MIT Press, Cambridge, Massachusetts. 